\title{
Automated feature extraction and spatial organization of seafloor pockmarks, Belfast Bay, Maine, USA
}

\author{
Brian D. Andrews ${ }^{a}, *$, Laura L. Brothers ${ }^{b}$, Walter A. Barnhardt ${ }^{a}$ \\ a U.S. Geological Survey, Woods Hole Coastal and Marine Science Center, 384 Woods Hole Rd. Woods Hole, MA 02543, USA \\ b University of Maine, Department of Earth Sciences, Orono, ME, 04469, USA
}

\section{A R T I C L E I N F O}

Article history:

Received 29 January 2010

Received in revised form 5 August 2010

Accepted 16 August 2010

Available online 20 August 2010

\section{Keywords:}

Pockmarks

Geomorphometry

Marine geology

Methane

\begin{abstract}
A B S T R A C T
Seafloor pockmarks occur worldwide and may represent millions of $\mathrm{m}^{3}$ of continental shelf erosion, but few numerical analyses of their morphology and spatial distribution of pockmarks exist. We introduce a quantitative definition of pockmark morphology and, based on this definition, propose a three-step geomorphometric method to identify and extract pockmarks from high-resolution swath bathymetry. We apply this GIS-implemented approach to $25 \mathrm{~km}^{2}$ of bathymetry collected in the Belfast Bay, Maine USA pockmark field. Our model extracted 1767 pockmarks and found a linear pockmark depth-to-diameter ratio for pockmarks field-wide. Mean pockmark depth is $7.6 \mathrm{~m}$ and mean diameter is $84.8 \mathrm{~m}$. Pockmark distribution is non-random, and nearly half of the field's pockmarks occur in chains. The most prominent chains are oriented semi-normal to the steepest gradient in Holocene sediment thickness. A descriptive model yields field-wide spatial statistics indicating that pockmarks are distributed in non-random clusters. Results enable quantitative comparison of pockmarks in fields worldwide as well as similar concave features, such as impact craters, dolines, or salt pools.
\end{abstract}

Published by Elsevier B.V.

\section{Introduction}

First identified in muddy sediments of the Scotian Shelf (King and MacLean, 1970), pockmarks are seafloor depressions that are found worldwide in a variety of geologic settings (Hovland and Judd, 1988; Judd and Hovland, 2007). These craters can measure hundreds of meters in diameter, may occur in chains kilometers long and, where present in extensive fields, may dominate the seafloor surface (Fader, 1991; Rogers et al., 2006; Pilcher and Argent, 2007). Despite global distribution and general association with seafloor fluid escape, the mechanisms for pockmark formation and evolution remain uncertain (Ussler et al., 2003).

Analysis of pockmark morphology and spatial distribution relative to antecedent geology and subsurface fluids (e.g., methane) can provide insight into fluid-migration pathways, pockmark field evolution, and possible mechanisms for pockmark generation and maintenance. In the absence of high-resolution seafloor bathymetry data, previous characterizations of entire pockmark fields relied upon visual interpretation of acoustic backscatter data for pockmark delineation, size statistics and spatial distribution (Fader, 1991; Kelley et al., 1994; Gontz et al., 2002; Rogers et al., 2006). Although acoustic backscatter data were the best available in the cited studies, interpreting size dimensions of concave features, such as pockmarks

\footnotetext{
* Corresponding author. Tel.: + 1508548 8700x2348; fax: + 15084572310 . E-mail address: bandrews@usgs.gov (B.D. Andrews).
}

from these data is often ambiguous (Song, 2007). High-resolution bathymetry data collected by multibeam echosounder and swath sonar technologies enable the study of seafloor morphology to reach scales and resolutions similar to studies in subaerial geomorphology based on digital elevation models (DEMs) (Hughes Clarke et al., 1996). With one exception (Webb et al., 2009) these new technologies have not been applied to an entire pockmark field. Instead, whole-field spatial and morphologic analysis has ebbed, replaced by characterization of small portions of a field or focus on individual pockmarks (Pilcher and Argent, 2007; Wildish et al., 2008). This change in emphasis is in part due to differing research objectives, but also is related to the challenges associated with feature extraction from acoustic data, particularly of features exhibiting complex morphologies that exist over an entire pockmark field.

This paper presents a novel method for pockmark feature extraction based upon the principals of geomorphometry and established algorithms for surface analysis (Pike, 1995). We apply this approach to a well-studied pockmark field located in Belfast Bay, Maine (Fig. 1). Our objectives are to: 1) develop a technique for pockmark identification and extraction, which may be applied to similar landforms/objects (e.g. planetary craters, thermokarst lakes, dolines, and salt pools); 2) apply this technique to high-resolution swath bathymetric data collected for the Belfast Bay field; and 3) characterize the spatial and morphological distribution of pockmarks in relation to the field's subsurface geology as determined from concurrently collected CHIRP seismic data, providing results that can 


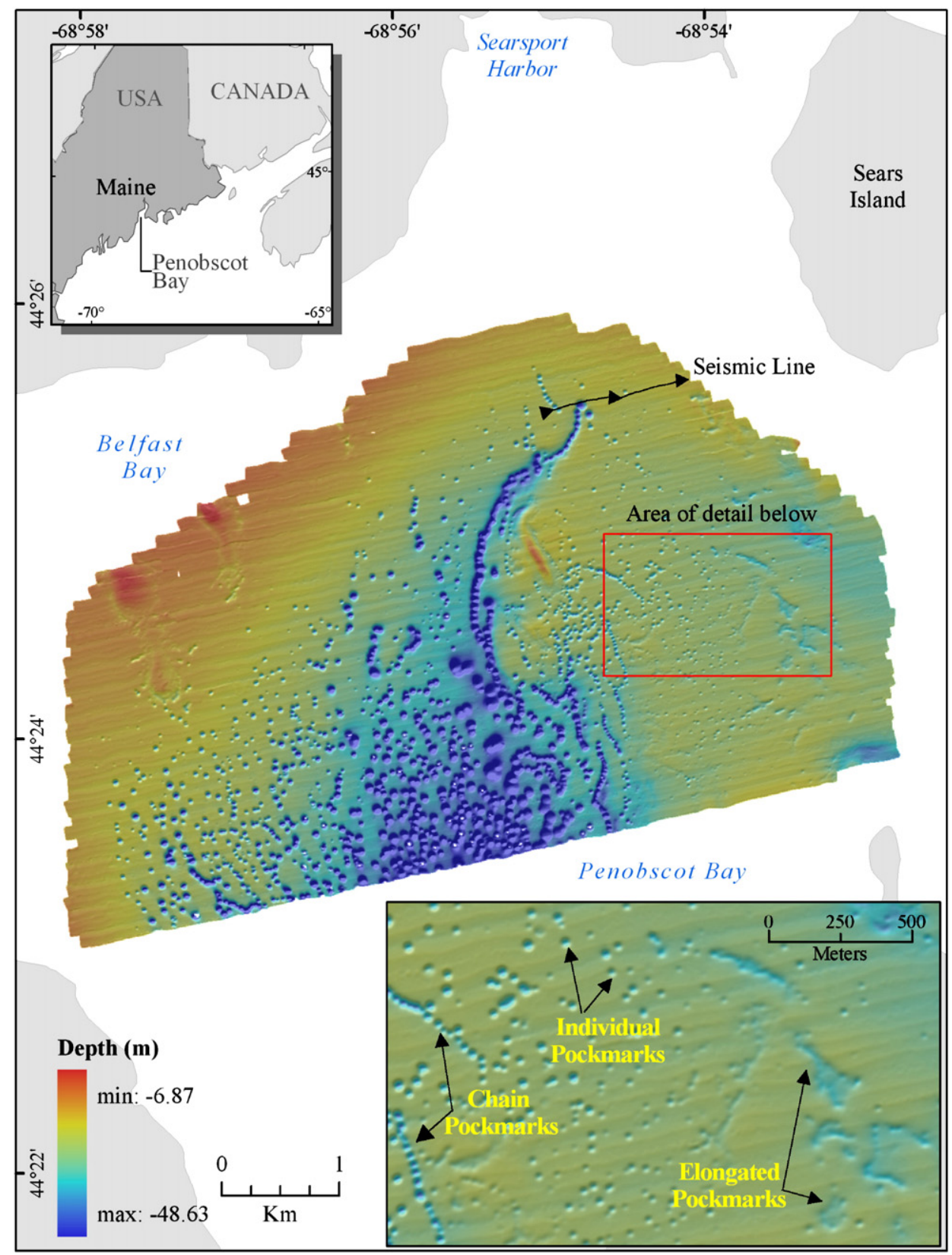

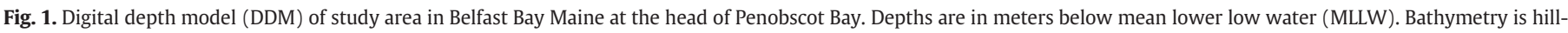

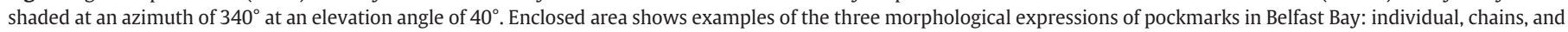
elongated pockmarks (after Hovland et al., 2002). Seismic line in northern part of survey area shows the location of Fig. 2.

serve as a baseline to which other fields worldwide may be compared quantitatively.

\section{Belfast Bay and regional geologic setting}

Belfast Bay is a shallow $(<70 \mathrm{~m})$ muddy embayment located near the head of Penobscot Bay in the northwestern Gulf of Maine (Fig. 1). It has a mean tidal range of $3.1 \mathrm{~m}$ and is fed from the northwest and northeast by the Passagassawakeag and Penobscot Rivers, respectively. The geology of the area is dominated by Paleozoic igneous and metamorphic rocks (Osberg et al., 1985). Differential erosion of bedrock shaped the irregular coast and inner shelf regions of Maine forming numerous estuaries and bays (Kelley, 1987; Barnhardt et al., 1996).
Seismic-reflection profiles show an acoustic basement that is typically Paleozoic bedrock or till deposited when late Wisconsinan glaciers retreated from the Maine coast between 15 and $13 \mathrm{ka}$ (Belknap et al., 1987; Barnhardt et al., 1997; Dorion et al., 2001) (Fig. 2). Inner shelf stratigraphy reflects changes in local sea level resulting from the isostatic effects of glaciation (Belknap et al., 1987; Barnhardt et al., 1995). Retreating glaciers scattered heterogeneous deposits of till across the present seafloor (Belknap and Shipp, 1991; Kelley and Belknap, 1991) and a series of moraines stretching across many coastal embayments, including Belfast Bay (Knebel, 1986; Shipp et al., 1987; Rogers et al., 2006). Deposited during glacial retreat, when sea level was $60-\mathrm{m}$ higher than the present coastline, the glacial-marine (GM) Presumpscot Formation muddy sediment (Bloom, 1963) covers rock and till seaward of the late Pleistocene marine limit, and is the most common deposit along the inner shelf of 


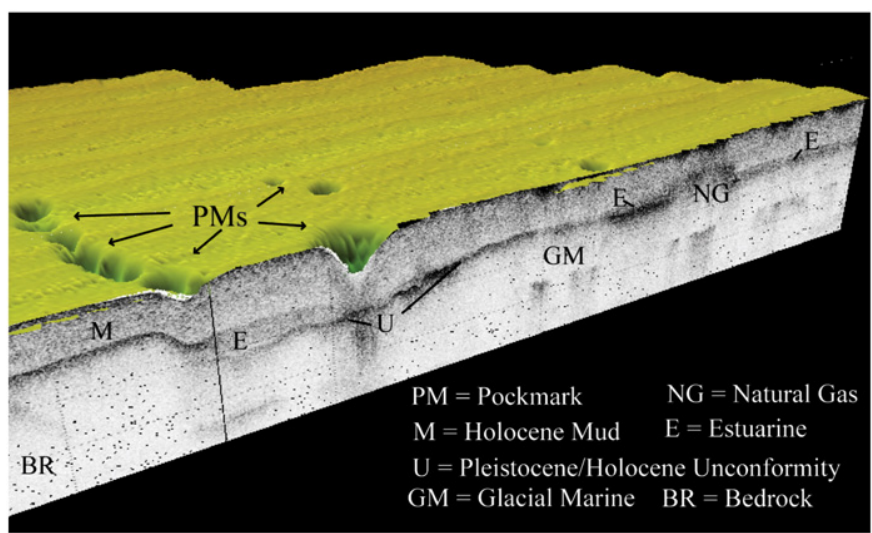

Fig. 2. CHRIP seismic line draped over swath bathymetry illustrates representative pockmark field and Gulf of Maine nearshore stratigraphy. Approximate distance between east and west extent of image is $1200 \mathrm{~m}$. Holocene mud thickness ranges between 5 and $10 \mathrm{~m}$. Pockmarks in Belfast Bay do not penetrate below the transgressive unconformity.

northern New England and the Canadian Maritimes (Kelley et al., 1998).

By $12.5 \mathrm{ka}$ (calibrated to calendar years with a $400 \mathrm{yr}$ reservoir correction; Reimer et al., 2009) isostatic uplift of the land had left sea level approximately $60 \mathrm{~m}$ below the present day shoreline (Barnhardt et al., 1995). Sea level has since risen at varying rates (Barnhardt et al., 1995; Kelley et al., 2010). Between the lowstand and the present shoreline lies a transgressive surface of erosion, with Holocene mud or sand overlying glacial sediment (Belknap et al., 1987; Belknap and Shipp, 1991; Barnhardt et al., 1997). In protected estuaries, such as Belfast Bay, a sandy-muddy estuarine (E) unit is locally preserved between GM and Holocene mud (Barnhardt et al., 1997).

Belfast Bay contains the most-studied pockmark field in eastern North America (Ostericher, 1965; Scanlon and Knebel, 1989; Kelley et al., 1994; Rogers, 1999; Gontz et al., 2002; Ussler et al., 2003; Rogers et al., 2006). Ostericher (1965) examined the Bay by seismic-reflection and identified "channels" in the sediment surface that he interpreted to be related to scour. Scanlon and Knebel (1989) conducted a sidescan-sonar survey in a similar part of the Bay and found the "channels" to be circular and similar to the features that King and MacLean (1970) discovered on the Scotian Shelf and termed 'pockmarks.' Enhanced reflectors and acoustic turbidity in seismic profiles from additional surveys indicated natural gas in the subsurface (Schubel, 1974; Scanlon and Knebel, 1989; Kelley et al., 1994; Rogers; 1999); the presence of methane was confirmed in further acoustic and vibracore work (Barnhardt et al., 1997). A sidescan-sonar survey by Rogers (1999) and a multibeam bathymetric survey conducted by NOAA in 1999 indicated that pockmarks dominate the Belfast Bay seafloor. Rogers (1999) identified approximately 2300 pockmarks over $32 \mathrm{~km}^{2}$ among them some of the world's largest and deepest nearshore pockmarks (Rogers et al., 2006). Despite these numerous investigations, fundamental questions about the field's origin and degree of activity persist (Kelley et al., 1994; Ussler et al., 2003).

\section{Data and methods}

\subsection{Geophysical data acquisition and processing}

High-resolution marine geophysical data were acquired in September 2006 for $25 \mathrm{~km}^{2}$ of the seafloor at depths ranging from 7 to $49 \mathrm{~m}$ (Fig. 1). Bathymetry, backscatter, and seismic-reflection data were collected simultaneously along $296 \mathrm{~km}$ of survey lines (northeast-southwest orientation) spaced $100 \mathrm{~m}$ apart. Acoustic backscatter data obtained from towed sidescan-sonar are not used here because the muddy sediments that cover the seafloor in Belfast Bay are well described elsewhere (Ussler et al., 2003; Rogers et al., 2006).

Bathymetric data were collected by a Systems Engineering \& Assessment (SEA) SwathPlus Interferometric sonar mounted on the bow of the $27^{\prime} \mathrm{R} / \mathrm{V}$ Rafael and operated at a frequency of $234 \mathrm{kHz}$. Survey speed was $\sim 5$ knots $\left(9 \mathrm{~km} \mathrm{~h}^{-1}\right)$. Precise navigation was provided by a Real-Time Kinematic Global Positioning System (RTKGPS) signal transmitted from a base station established onshore. The RTK-GPS signal was used to establish the height of the vessel's GPS antenna relative to mean lower low water (MLLW). Sound-velocity casts were collected every 2-3 h during the survey to correct for changes in the speed of sound within the water column.

Raw bathymetric data collected in SwathPlus format were processed through SEA Swath Processor software and converted to a SwathPlus processed file. Bathymetric filters were applied to clean the data, and the sound-velocity profiles, RTK tides, transducer roll, and antenna offsets were also applied. The filtered processed file was then imported to Computer Aided Resource Information System (CARIS) Hydrographic Information Processing System (HIPS) for final manual line-by-line editing. The bathymetric sonar did not completely ensonify the bottoms in several of the deeper pockmarks because of the rapid change in depth. Any "no data" values at the bottom of these pockmarks were interpolated using a $3 \times 3$ median filter in CARIS. The final depth surface was exported from CARIS to Environmental Systems Research Institute (ESRI) Geographic Information System (GIS) software ArcGIS to generate a 32-bit floating-point bathymetric grid of $5 \times 5 \mathrm{~m}$ cells - the basis of all subsequent analysis.

Seismic-reflection profile data were collected simultaneously with the bathymetry by an EdgeTech FSSB 424 system towed approximately $2 \mathrm{~m}$ astern of the R/V Rafael and operating at $4-24 \mathrm{kHz}$. The data were acquired in SEG_Y format and processed in SioSeis and SeismicUnix.

Each seismic profile was interpreted in Landmark Graphics to delineate both the Pleistocene/Holocene unconformity surface and the presence of acoustic turbidity and enhanced reflectors interpreted as gas (Fig. 2). The $x, y$, and $z$ values of the interpreted horizon were exported at a spacing of every 20 shot points (approximately $13 \mathrm{~m}$ ). A continuous surface, using the Triangulated Integrated Network (TIN) Model, was then converted to a regular grid (25-m resolution) showing Holocene thickness.

\subsection{Geomorphometric methods}

\subsubsection{A representation of surface form}

The qualitative description and segmentation of landforms (e.g. hilly, steep, and rough) in terrestrial geomorphology are subjective and often insufficient for comparative studies (Pike, 1995). A more robust quantitative approach to empirically describe the shape of the earth's surface can facilitate the detailed interpretation of individual landform units and across various landform types (Pike, 1995, 2000; Pike et al., 2009). The mathematical description of planetary surfaces and the extraction of surface-form parameters and objects are known as geomorphometry. This morphological approach adapts to the seafloor and extraterrestrial surfaces; it combines with the traditional tools of geomorphology to sharpen the interpretation of naturally occurring forms anywhere. We find this approach suited for the analysis and interpretation of seafloor pockmarks.

Although individual pockmarks appear symmetrical and visually distinct in hill-shaded digital depth models (DDM), their morphologies can be complex (Fig. 1; Hovland and Judd, 1988). Such irregularities complicate pockmark delineation based on visual inspection. Further, pockmark fields may comprise thousands of features and manual interpretation becomes impractical in addition to implicitly subjective. Consistent and repeatable delineation of pockmarks by automated techniques requires a morphologic definition that includes diagnostic features and distinguishes them from other 
forms. We define a pockmark as a roughly circular seafloor depression that consists of three elements: 1) the depth to the lowest point (bottom) of the depression; 2) the depth to the rim; and 3) the diameter of the rim defined here operationally by the intersection of pseudo-"watershed boundary" and the nominally flat seafloor. This rim also marks the locus of greatest change in slope gradient (profile curvature) at each pockmark (Fig. 3). Most pockmarks in Belfast Bay and worldwide are sufficiently described by this definition; however, it does not adequately characterize "elongated pockmarks" which have irregular highs and lows throughout the depression (Fig. 1; Hovland et al., 2002). In Belfast Bay these elongated forms occur at the periphery of the field, and are not the dominant pockmark expression.

\subsubsection{Initial approximation of pockmark shape}

Differences between 2-D and 3-D descriptions of pockmark form pose several challenges to their automated extraction. In 2-D, pockmarks appear as simple symmetrical features (Fig. 3), while in 3-D, pockmark depth, slope, and curvature gradient vary within each occurrence. Because the distribution of profile curvature varies among pockmarks of different sizes, we first represent pockmarks as point features and then attempt to identify geomorphic attribute(s) that consistently define a perimeter or rim for all pockmarks. This approach facilitates extraction from the background seafloor even where pockmarks have elongated rims or exist in chains (Fig. 1).

\subsection{Pockmark extraction}

We characterize a pockmark as a point feature in a digital depth model (DDM) by employing standard hydrologic algorithms to identify the lowest point in the depression. This approach has been previously used in watershed studies to identify subaerial sinks, or pits, typically artifacts of DEM generation (Jenson and Domingue, 1988; Gallant and Wilson, 2000), and to subsequently fill them prior to stream network delineation. Using these algorithms we located the point in each pockmark (i.e. sink) where, on land, water would collect, and defined that location as the pockmark bottom. Thus identified, the bottoms of all pockmarks were populated with additional attributes including seafloor depth of the center of the rim $\left(z_{1}\right)$ and seafloor depth of the pockmark bottom $\left(z_{2}\right)$ (Fig. 4). Three general analytic steps calculate the two basic quantities defining the geometry of each pockmark depth $\left(d=\left|z_{1}-z_{2}\right|\right)$ and diameter $(D)$ (Fig. 4). Each step represents a different geoprocessing model compiled in ArcGIS (ver. 9.2) Modelbuilder. The 30 geoprocessing steps run from the three basic models are summarized below (Fig. 5).

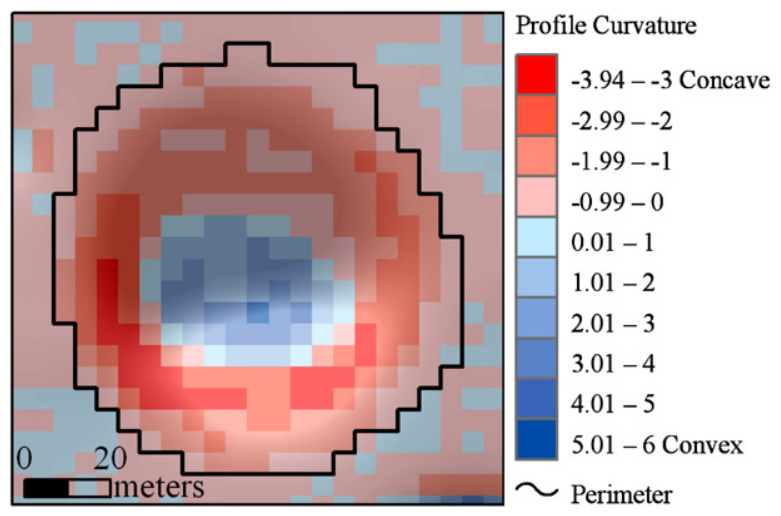

Fig. 3. Plan view of single pockmark color-coded by profile curvature (the rate of change in slope gradient) draped over hill-shaded bathymetry. Red cells (negative values) are convex and blue (positive values) cells are concave in the direction of greatest slope. Curvature calculations are based on the DDM with negative depth values. Black outline is pockmark perimeter (rim) derived from the intersection of watershed delineation and slope mask described in Section 3.3.

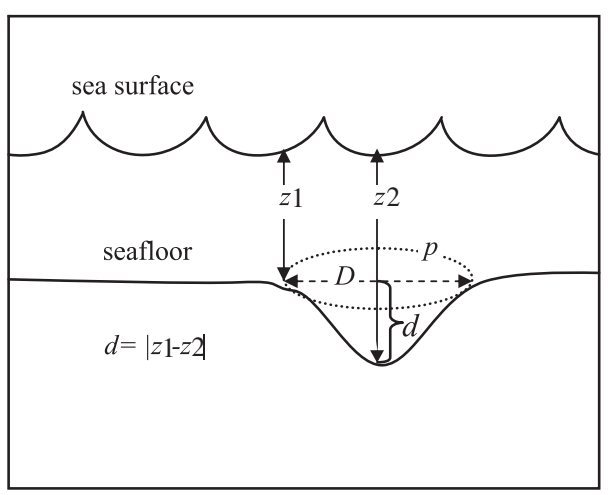

Fig. 4. Simplified illustration of an individual pockmark as described in this study. $z_{1}$ is the seafloor depth in meters below mean lower low water of the center of the rim, $z_{2}$ is the seafloor depth in meters below mean lower low water of the lowest point in the bottom. $d=$ the absolute depth difference in meters between $z_{1}$ and $z_{2} . D=$ diameter of the rim in meters. $p$ is the perimeter of the rim in meters.

\subsubsection{Sink identification and extraction}

The first step in extracting the pockmark bottom, is calculating a pseudo flow direction for the entire DDM. Flow direction was derived for each grid cell by identifying the maximum change in $z$-value (MaxSlope) between each center cell and the eight adjacent cells (Jenson and Domingue, 1988) (Fig. 5, step 1.1; Figs. 6 and 7).

$$
\text { MaxSlope }=\max \left(\frac{z_{i}-z_{0}}{r}\right)\left\{\begin{array}{ll}
r=5 & i=2,4,6,8 \\
r=5 \sqrt{2} & i=1,3,5,7
\end{array}\right. \text {. }
$$

Flow direction is then encoded using integer notation (Fig. 6), modified after Gallant and Wilson (2000). The coded integer value (1, $2,4,8$, etc.) is arbitrary and can change depending on the software. ESRI software starts with 1 as flowing to the east (right), but in other programs the flow may start in a different cell (Jenson and Domingue, 1988).

We identify the sink as the cell, or number of contiguous cells, that is lower than its surrounding neighbors and has an undefined flow direction (Fig. 5 Step 1.2; Fig. 6). This step produces a grid of one or

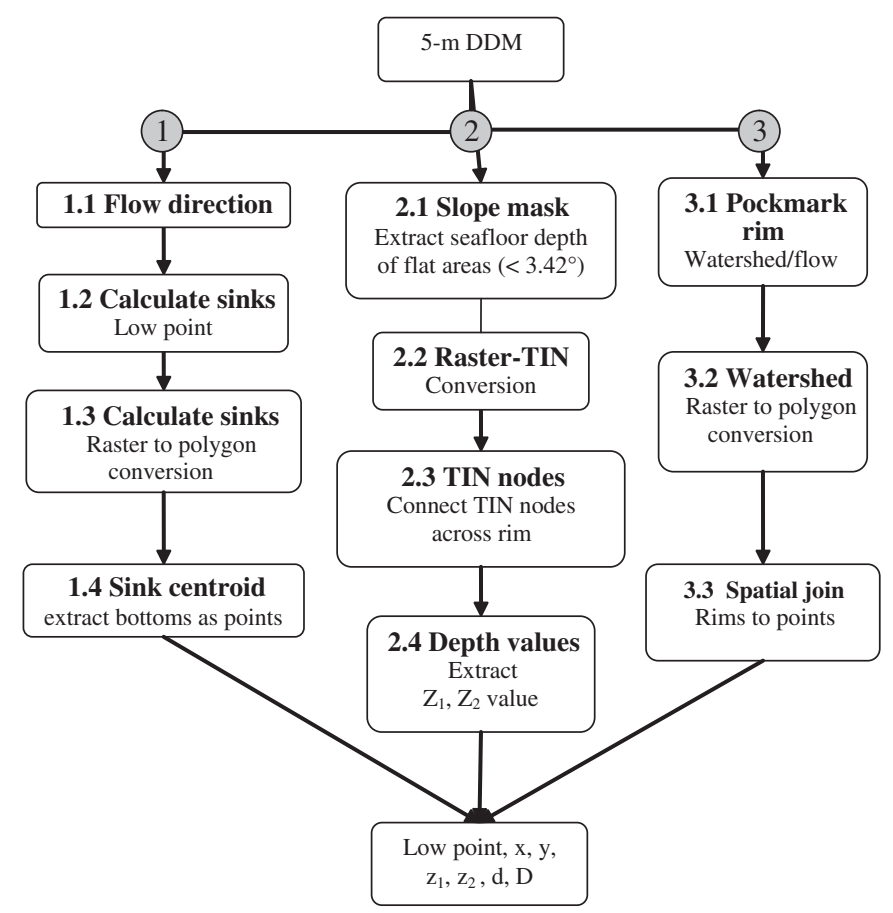

Fig. 5. Generalized flow diagram showing the three central processing routines that extract the pockmark features and derive dimension attributes. 


\begin{tabular}{|c|c|c|}
\hline \\
\hline 28.07
\end{tabular}

Fig. 6. Example of automated pockmark extraction from a digital depth model (DDM). The center of each $5-\mathrm{m}$ cell in the $3 \times 3$ matrix is labeled on the bottom of cell by seafloor depth (negative values), and on the top with the coded integer value calculated using the flow-direction algorithm. Middle and center top cells flow into each other because $0.05-\mathrm{m}$ depth difference between the two cells exceeds the function precision. As a result, the two cells were identified as a $5 \times 10 \mathrm{~m}$ sink. The polygon centroid locates the pockmark bottom (green circle).

more 5-m cells for each pockmark (Fig. 5, step 1.3) representing the lowest point (or bottom).

For each pockmark the locations identified as sinks were either a single 5 -m cell or two $5 \times 5$ cells (i.e. one $5 \times 10 \mathrm{~m}$ ) depending on the slope of the floor. Larger pockmarks can have larger flat bottom areas covering more than one 5 -m cell value. Smaller pockmarks have smaller flat areas that can be represented by one $5-\mathrm{m}$ cell. The centroid of the sink cell(s) locates the pockmark bottom (Fig. 5, step 1.3; Figs. 6 and 7) and is extracted as a point feature (Fig. 5, step 1.4; Fig. 7).

\subsubsection{Extracting pockmarks from adjacent seafloor}

The second group of processing steps calculates seafloor surface depth attributes for the point locations of pockmark bottoms (Fig. 5, step 2.0). The seafloor depth value of the center of the $\operatorname{rim}\left(z_{1}\right)$ for each pockmark was extracted from a "flat earth model" built from the nominally flat seafloor adjacent to each pockmark. We applied a digital mask of areas with slope $<3.42^{\circ}$ (mean slope of DDM) to extract bathymetric data of the "flat" areas surrounding the pockmarks (Fig. 5, step 2.1). This 5-m bathymetric grid representing only the flat areas was then converted to points that served as input to a triangulated irregular network (TIN) as mass points (Fig. 5, step 2.2).

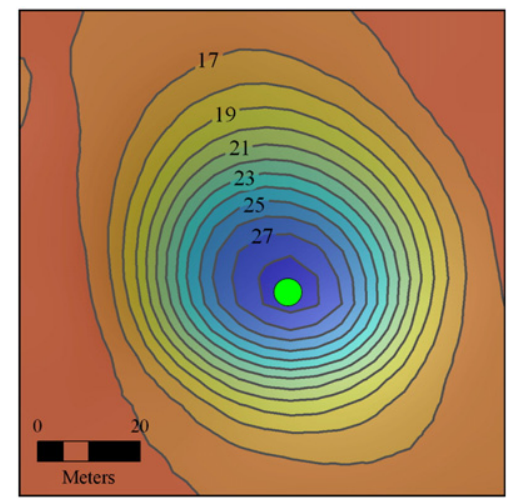

Fig. 7. Single pockmark showing location of the feature's bottom (green circle). Red box shows the extent of Fig. 6. Depth contour interval is $1 \mathrm{~m}$.
The TIN model connects the depth-point values across the rim of the pockmark effectively creating a "top" surface for each pockmark and producing a generalized flat seafloor (Fig. 5, step 2.3) over the survey area. The depth (pockmark top) of the "flat earth" seafloor $\left(z_{1}\right)$ was appended to the $x, y$ location of the pockmark bottom $\left(z_{2}\right)$. The absolute difference of these two depth values is the overall depth $(d)$ dimension of the pockmark (Figs. 4 and 5, step 2.4).

\subsubsection{Defining pockmark rim}

Representing the rim of each pockmark as a discrete isoline posed the greatest obstacle. Visual observation in 2-D (Fig. 3) and 3-D (Fig. 4) shows the edge of a pockmark not as a raised rim but rather as a gradual change in slope and curvature. Variability of these two attributes within each pockmark, and between pockmarks, precludes using an absolute value of slope (e.g. $4^{\circ}$ ) or curvature (e.g. -3.0 ) to define the pockmark rim. To solve this problem we relied on the watershed we employed successfully in the first step to locate the pockmark rims. The watershed delineation finds all upslope areas that "flow" into the bottom of the pockmark and delineates this edge as a polyline. In this study this polyline represents the rim of a pockmark.

The digital "watershed" for each pockmark was calculated from the flow-direction raster (Fig. 5, step 1.1) along with the pockmark points (Fig. 5, step 1.2) to identify the contiguous cells (i.e. watershed) that flow to the bottom of each pockmark. We confined the watershed analysis to cells with slopes greater than $3.42^{\circ}$ using the slope mask derived in Section 3.2.2. All cells in each watershed are coded with the same attribute as the pockmark point in the center. All raster cells of each watershed are converted into one polygon encompassing each pockmark bottom, and then merged with the pockmark point using a spatial join (Fig. 5, step 3.3). This last step added the final descriptor, perimeter $(p)$, required for our analysis. Other studies generally use rim diameter to describe $x, y$ extent (Yun et al., 1999; Rogers et al., 2006; Wildish et al., 2008). Although most of Belfast Bay's pockmarks are essentially circular, those at the periphery of the field, adjacent to till outcrops and generally within thinner sediment deposits, may be elongated. To facilitate comparison with other studies, we treat pockmark rims as a uniform circle and calculate diameter along with perimeter. The number of pockmark bottoms generated in step 1.4 in Fig. 5 may not equal the number of rims, depending upon quality of the sonar data in deeper areas. Our study identified 60 more bottoms than perimeters. This discrepancy reflects the tendency for two pockmark bottoms to occur within the "watershed" of an elongated pockmark, or within a poorly imaged pockmark. To control data quality we manually eliminated the redundant point features.

\section{Results}

\subsection{Model accuracy}

The model extracted 1767 (Fig. 8) of the 1844 pockmarks found by visual inspection of the hill-shaded bathymetry. All pockmarks delineated using our method were also identified manually, although model-generated perimeters for some of the shallow elongated pockmarks were more easily identified than those delineated visually.

We attribute this 77 count discrepancy to: 1) subjectivity implicit in visual identification of the features, particularly elongated pockmarks; and 2) missing bottoms for the deepest pockmarks where the operational limits of our bathymetric sonar were exceeded (Fig. 1). Pockmarks identified visually but not by our model occurred predominantly at the periphery of the field, either to the south where maximum depths were beyond the resolution of our sonars (and large data gap could not be filled in by interpolation), or to the east and west where elongated pockmarks, or small pockmarks ( $<5 \mathrm{~m}$ diameter) with irregular rims are located. 


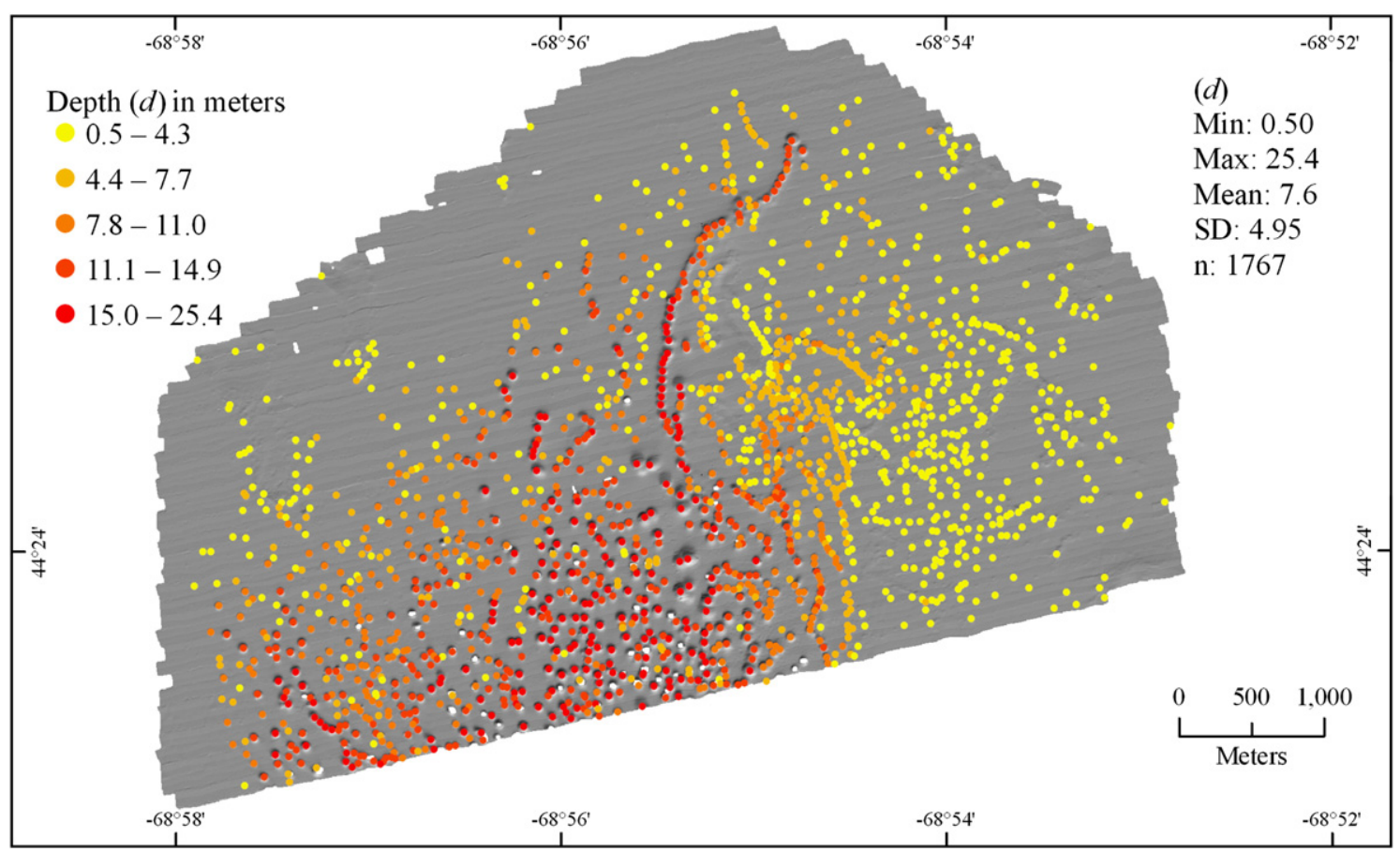

Fig. 8. Locations of 1767 pockmark bottoms $\left(z_{2}\right)$ plotted by depth dimension $(d)$, displayed over gray scale hill-shaded bathymetry.

\subsection{Pockmark morphometry}

Descriptive measurements for the 1767 pockmarks are summarized in Table 1 . Mean pockmark depth $(d)$ over the entire field is $7.6 \mathrm{~m}$, mean perimeter length $(p)$ is $266.5 \mathrm{~m}$, and mean diameter $(D)$ is $84.8 \mathrm{~m}$. There is a strong correlation $\left(R^{2}=0.902\right)$ between seafloor depth $\left(z_{2}\right)$ and pockmark depth $(d)$ (Fig. 9), the larger pockmarks occurring in deeper water. The relation between $d$ and rim diameter $(D)$ is strong $\left(R^{2}=0.61\right.$; Fig. 10$)$, showing that most are not scale dependent features.

Pockmarks commonly occur in chains (Hovland et al., 2002) and the Belfast Bay field is no exception. To further evaluate morphology we classified each extracted pockmark as a single or chain feature (Table 2). We define a chain pockmark as two or more pockmarks sharing a wall, or combined rim. Of the 1767 pockmarks identified, 917 (52\%) are single and 850 (48\%) are chain features. Over a third of all pockmarks identified as chains consist of only two features (282), but the most extensive chain consists of 51 pockmarks (Fig. 11). Chain pockmarks are twice as broad $(D)$ and deep $(d)$ as single pockmarks: 102 and $10.4 \mathrm{~m}$, compared to 69.1 and $5.17 \mathrm{~m}$ respectively. Chain pockmarks occupy more of the surveyed seafloor than single pockmarks: $3.68 \mathrm{~km}^{2}$ compared to $2.20 \mathrm{~km}^{2}$.

Belfast Bay seafloor slopes range from 0 to $44.8^{\circ}$. Values of $3.24^{\circ}$ or less characterize the background seafloor, while the highest slopes describe the pockmark walls (Fig. 12). Pockmark sidewalls are commonly steeper than the proposed angle of repose $\left(20^{\circ}\right)$ for

Table 1

Statistics for ocean depth $\left(z_{2}\right)$, depth to pockmark rim $\left(z_{1}\right)$, pockmark depth $(d)$, perimeter $(p)$ and diameter $(D)$ of the 1767 pockmarks.

\begin{tabular}{lrccc}
\hline Parameter & Min $(\mathrm{m})$ & Max $(\mathrm{m})$ & Mean $(\mathrm{m})$ & $\begin{array}{c}\text { Standard } \\
\text { deviation }(\mathrm{m})\end{array}$ \\
\hline Seafloor depth $\left(z_{2}\right)$ & 10.21 & 48.73 & 26.02 & 6.78 \\
Depth to pockmark & 9.50 & 25.70 & 18.00 & 2.59 \\
$\quad$ rim $\left(z_{1}\right)$ & & & & \\
Pockmark depth $(d)$ & 0.54 & 25.43 & 7.60 & 4.95 \\
Perimeter $(p)$ & 50.00 & 950.00 & 266.50 & 119.70 \\
Diameter $(D)$ & 15.90 & 302.00 & 84.80 & 38.10 \\
\hline
\end{tabular}

submarine sedimentary deposits (Booth et al., 1985). Pockmarks flatten out at the bottom and slope at $0-12^{\circ}$. The rate of change of slope (profile curvature) ranges from -42.97 (convex at pockmark rim) to 39.16 (concave at pockmark bottom) (Figs. 3 and 12). Chain pockmarks are steeper, and of greater curvature than single pockmarks (Table 3; Fig. 13).

Pockmarks occupy $5.88 \mathrm{~km}^{2}$, or $24 \%$, of the surveyed seafloor. Subtract the fields' DDM from the "flat" TIN-created DDM in Section 3.3.2 (Fig. 5, step 2.1) yields the field-wide volume of pockmarks. Assuming there has been no significant sediment deposition since pockmark formation, Belfast Bay pockmarks account for $1.5 \times 10^{7} \mathrm{~m}^{3}$ of displaced volume within the surveyed area. This amount is less than previous estimations based on modeled pockmark morphology derived from minimally available fathometer traces $\left(9.9 \times 10^{7} \mathrm{~m}^{3}\right.$ by Kelley et al., 1994 ; and $2.69 \times 10^{7} \mathrm{~m}^{3}$ by Rogers et al., 2006). Other explanations for the discrepancy include differences in areal extent between the three studied areas and a geopositioning error in the first survey (Rogers, 1999).

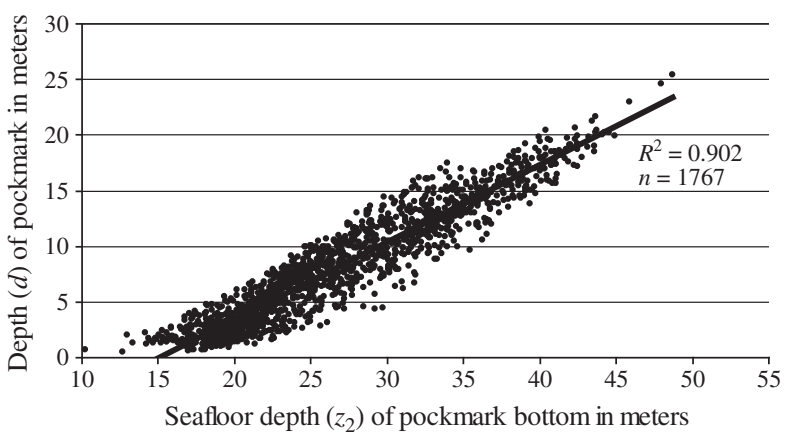

Fig. 9. Relation between depth of seafloor at bottom $\left(z_{2}\right)$ pockmark depth $(d)$ for the 1767 pockmarks. $R^{2}=0.902$. 


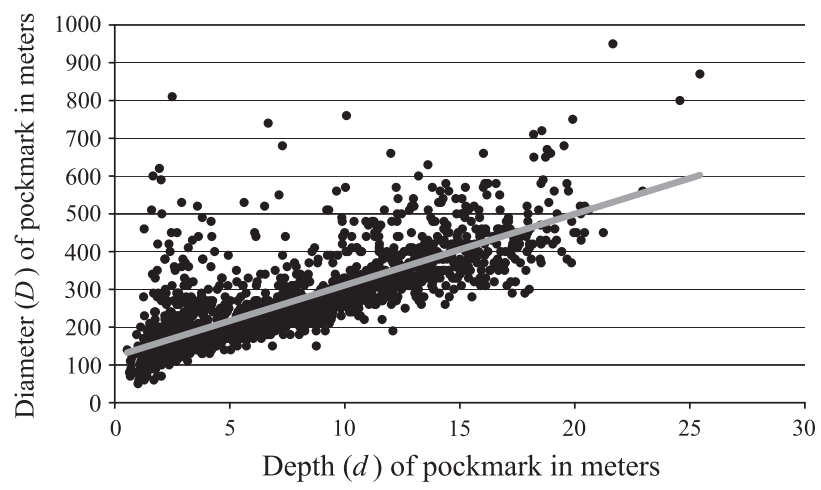

Fig. 10. Relation between pockmark depth $(d)$ and rim diameter $(D)$ for the 1767 pockmarks. $R^{2}=0.6107$

\subsection{Relation to subsurface characteristics}

The spatial distribution of the 1767 pockmarks within the $25 \mathrm{~km}^{2}$ survey area was investigated for trends in their location using the average nearest neighbor method. The average Euclidian distance between each pockmark was compared to a hypothetical random distribution of their locations within the survey area. The ratio of observed/expected average distance for the field is 0.97 with a $p$-value of 0.017 resulting in a clustered pattern. There is less than 5\% likelihood that the clustered pattern is the result of random chance. We explain this pattern by relating pockmark morphology and distribution to subsurface characteristics including Holocene sediment thickness and the presence of subsurface natural gas. Holocene deposits range in thickness from 0 to $34 \mathrm{~m}$ and are thickest in the center of the field and in a smaller basin in the southwestern portion of the field (Fig. 11).

A total of $19.7 \mathrm{~km}^{2}$, or $78 \%$, of the total survey is contained in Holocene sediment thickness in the $0-11.7 \mathrm{~m}$ range. Forty percent of all pockmarks occur in Holocene deposits less than $11.7 \mathrm{~m}$ thick (Table 4). Pockmarks in this range have a mean relief and diameter of 3.20 and $60.8 \mathrm{~m}$ respectively. Because the bottoms of pockmarks terminate at or above the base of the Holocene unit, pockmark depth is limited by the thickness of those deposits. Pockmarks in the relatively thin sediments are smaller and shallower than those in deeper sediments (Table 4). Pockmarks occupy $1.14 \mathrm{~km}^{2}$, or $6 \%$, of the field underlain by Holocene sediment thinner than $11.7 \mathrm{~m}$. Nearest neighbor analysis of pockmark locations reveals that the most concentrated clustering occurs within this zone of sediment thickness, particularly at the southern toe of a till deposit in the northeast quadrant (Fig. 12). The remaining $60 \%$ of pockmarks in Holocene sediment exceeding $11.7 \mathrm{~m}$ in thickness occupy $5.6 \mathrm{~km}^{2}, 22 \%$ of the

Table 2

Statistics for ocean depth $\left(z_{2}\right)$, depth to pockmark rim $\left(z_{1}\right)$, pockmark depth $(d)$, perimeter $(p)$ and diameter $(D)$ of pockmarks classified as chains or single features.

\begin{tabular}{lcccr}
\hline & Min $(\mathrm{m})$ & Max $(\mathrm{m})$ & Mean $(\mathrm{m})$ & SD $(\mathrm{m})$ \\
\hline Single & & & & \\
$z_{2}$ & 10.20 & 41.70 & 22.50 & 4.72 \\
$z_{1}$ & 9.50 & 24.40 & 17.30 & 1.94 \\
$d$ & 0.55 & 18.80 & 5.17 & 3.74 \\
$p$ & 50.00 & 810.00 & 217.00 & 100.00 \\
$D$ & 15.90 & 258.00 & 69.10 & 31.80 \\
& & & & \\
Chain & & & & 6.53 \\
$z_{2}$ & 14.47 & 48.73 & 29.90 & 2.67 \\
$z_{1}$ & 12.80 & 25.80 & 19.60 & 4.69 \\
$d$ & 1.01 & 25.40 & 10.40 & 115.00 \\
$p$ & 90.00 & 950.00 & 320.00 & 36.60 \\
$D$ & 28.60 & 302.00 & 102.00 & \\
\hline
\end{tabular}

surveyed area. Natural gas underlies these areas (Fig. 12) and pockmarks dominate $82 \%\left(4.6 \mathrm{~km}^{2}\right)$ of the seafloor. In these thicker Holocene deposits mean pockmark relief and diameter are 10.5 and $100 \mathrm{~m}$ respectively.

CHIRP seismic data reveal acoustic turbidity and enhanced reflectors in $6.1 \mathrm{~km}^{2}(24 \%)$ of the total survey area. Enhanced reflectors are most often visible at the Pleistocene/Holocene unconformity and in close proximity to till outcrops. Zones rich in gas bubbles typically occur $5-10 \mathrm{~m}$ below the seafloor (Fig. 2) and generally coincide with sediments thicker than $11.8 \mathrm{~m}$ (Fig. 11). All Holocene sediment deposits thicker than $17 \mathrm{~m}$ are underlain by gas, while gas is absent in areas of minimal Holocene sediment thickness $(0-6.4 \mathrm{~m})$.

\section{Discussion}

\subsection{Model performance and constraints}

The results of this study illustrate a successful adaptation of subaerial methods to the marine environment that should contribute to further quantitative investigations of the morphology of the seafloor. We define a pockmark as a specific surface element within the continuous seafloor, here delimited by high-resolution bathymetry and the methodological approach of geomorphometric principles (Pike, 1995, 2000; Pike et al., 2009). We express a pockmark as a discrete unit in both two and three-dimensional spaces; its form provides attributes for object-oriented modeling of the seafloor. The methods developed here intentionally chose algorithms commonly available in existing terrain analysis software (see Section 2 in Hengl and Reuter, 2009) to maximize applicability.

Although our approach delivered robust results for Belfast Bay, several limitations exist. 1) For simple pockmarks the model identifies and quantifies two key form elements: a central low point (bottom) and a rim as defined by watershed flow-direction routines. In many fields, such as Belfast Bay, these two elements suffice for most pockmarks. They do not adequately characterize elongated pockmarks with multiple sinks, highly asymmetric pockmarks or flute-like features that occur at the seaward terminations of some pockmark fields (Fader, 1991). Further refining the pockmark definition to include multiple low points within one rim may be required for some fields. 2) Our model is somewhat scale dependent in that we are ignoring the incipient pockmarks smaller than our 5-m resolution. In addition, operational limitations (depth penetration) of the bathymetric sonar yield no data in some of deeper pockmarks in the southern survey area. The broad spatial scale of our regional approach $\left(25-50 \mathrm{~km}^{2}\right)$ focuses on larger features that are sufficiently represented by a $5-m$ pixel resolution.

\subsection{Pockmark morphology}

Pockmark forms observed in the Belfast Bay pockmark field and spatial clustering are common to other fields (Hovland and Judd, 1988; Pilcher and Argent, 2007; Webb et al., 2009). Extracted pockmarks in Belfast Bay have a consistent depth/diameter ratio across the field (Fig. 10), similar to ratios observed in pockmark fields in the Scotian Shelf (Fader, 1991) and Inner Oslofjord of Norway (Webb et al., 2009).

Despite several studies of the relation between pockmarks and host sediment thickness (Josenhans et al., 1978; Fader, 1991; Rogers et al., 2006; Webb et al., 2009), pockmark morphology does not necessarily constrain a correlation between pockmark size and host sediment thickness. Pockmarks in any one field may span a range of morphologies (Judd and Hovland, 2007). Such heterogeneity complicates size parameterization.

Depth (e.g. relief) and diameter primarily describe pockmark size (Hovland and Judd, 1988; Judd and Hovland, 2007). In fields, such as 


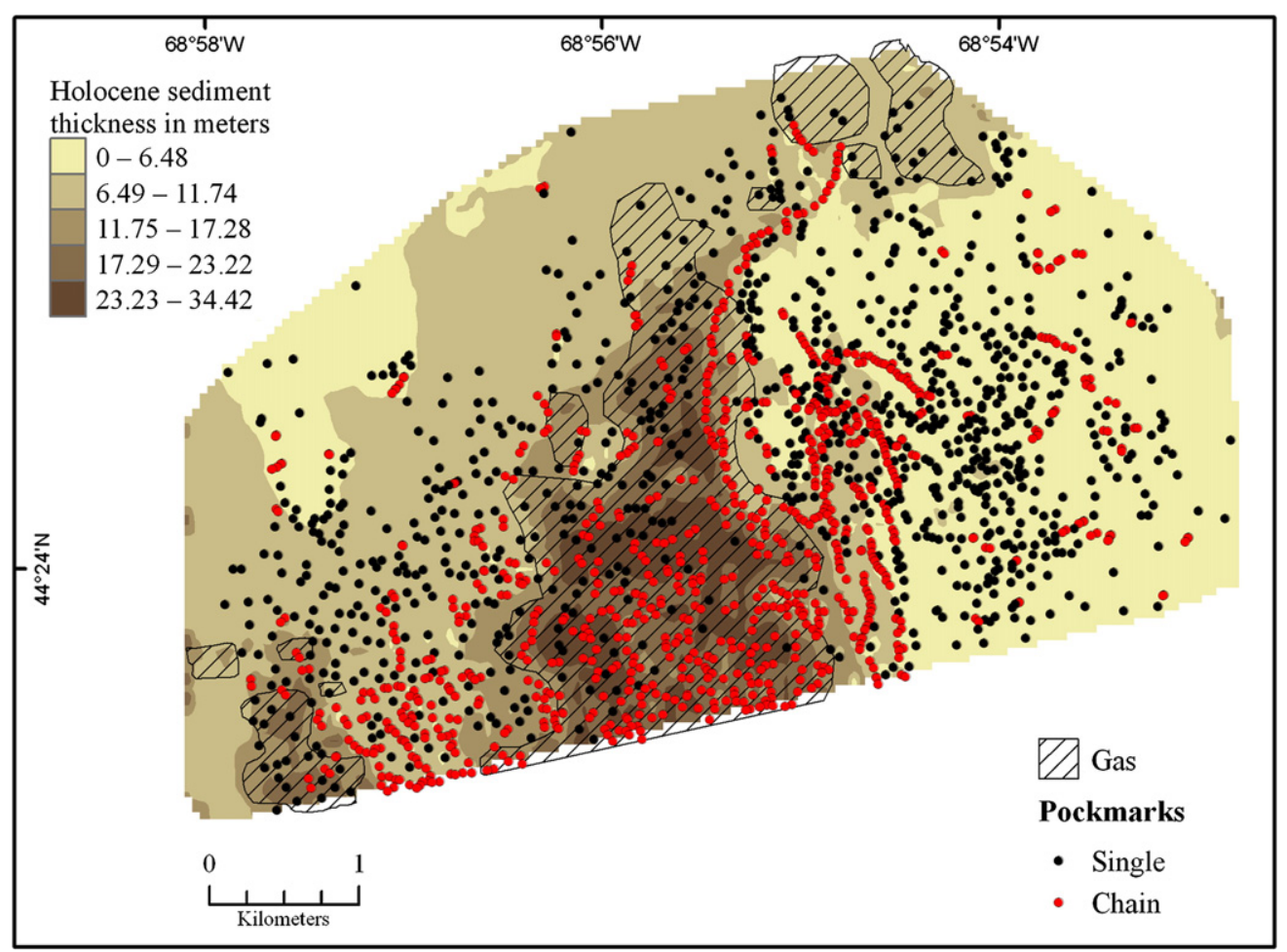

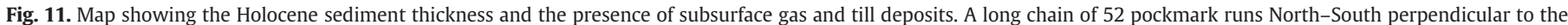
steepest gradient in Holocene sediment thickness is located at the center of the map.

Belfast Bay, where pockmarks have a consistent depth/diameter ratio, either one of these parameters makes a meaningful size statistic for intra-field comparison. However, these parameters are less useful in conveying gross pockmark size in fields with a wide range in depthto-diameter ratios. In such cases field-wide comparisons require such parameters as pockmark surface area or volume displacement to compare pockmarks by size.

In Belfast Bay, pockmarks that deviate from the linear relation between depth $(d)$ and diameter $(D)$ typically are shallower with respect to diameter. These anomalies occur mainly on the periphery of the field, adjacent to till outcrops and in thinner deposits of sediment. These are some of the broadest in Belfast Bay $(p=810 \mathrm{~m})$ but may be less than $4 \mathrm{~m}$ in depth.

Despite the presence of these large shallow depressions, pockmarks in the thinnest sediment layers are smaller than those in any other isopach (Table 4). Examination of field-wide seismic-reflection profile data indicates that pockmarks do not penetrate below the Pleistocene/Holocene unconformity. Therefore the field's largest

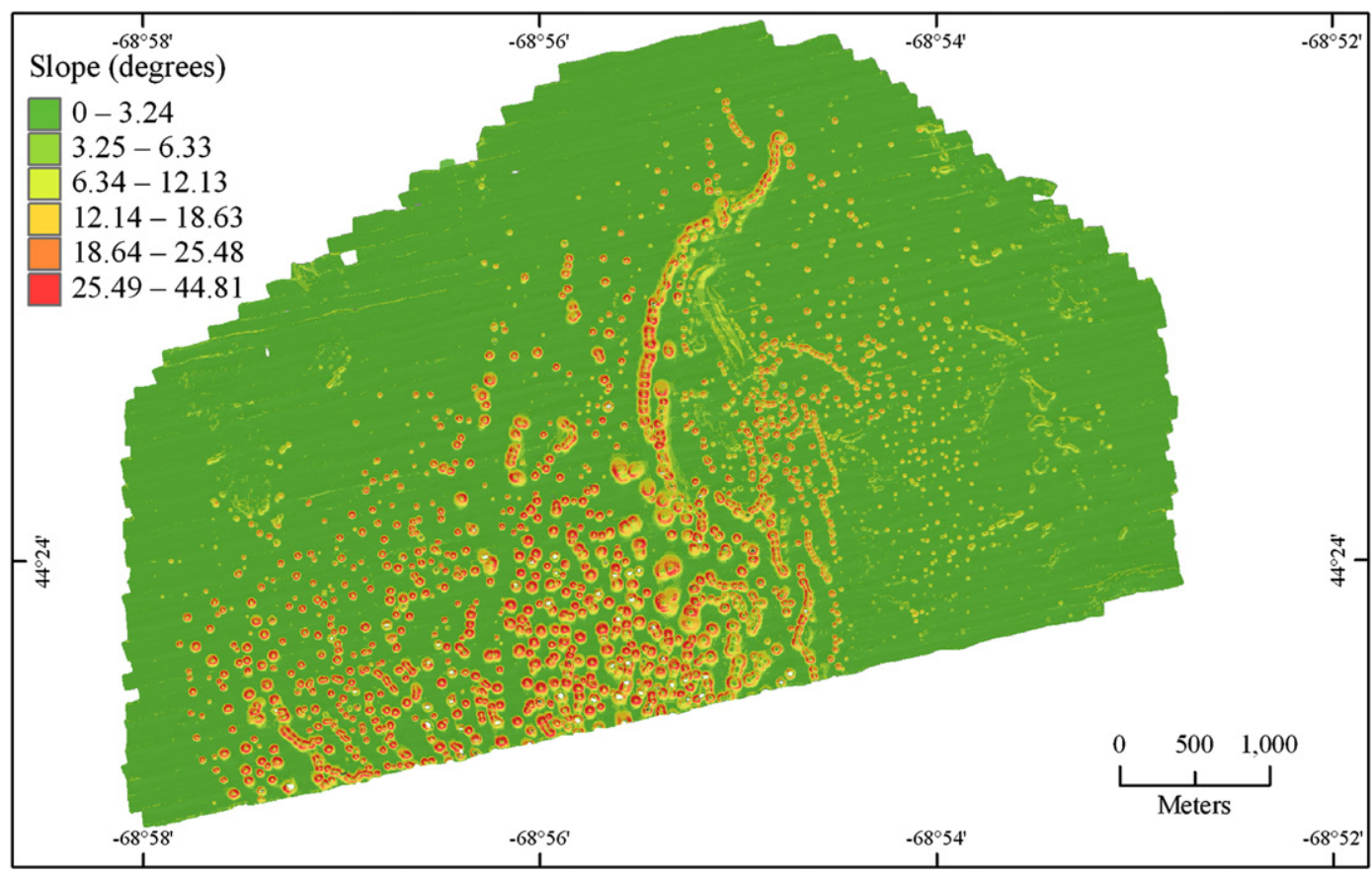

Fig. 12. Slope gradient map of bathymetry in the survey area showing nominally flat seafloor $\left(\leq 3.24^{\circ}\right.$ slope $)$ and steeper pockmark walls with slopes exceeding $3.24^{\circ}$. 
Table 3

Summary statistics for slope and curvature for single and chain pockmarks; all values in degrees.

\begin{tabular}{lrrrr}
\hline & \multicolumn{1}{c}{ Min } & Max & Mean & SD \\
\hline Single pockmark & & & & \\
Slope & 1.03 & 18.20 & 8.04 & 5.12 \\
Curvature & -3.10 & 3.81 & -0.59 & 1.41 \\
& & & & \\
Chain pockmark & & & & \\
Slope & 1.01 & 27.00 & 11.40 & 2.40 \\
Curvature & -3.80 & 4.46 & -0.64 & 1.58 \\
\hline
\end{tabular}

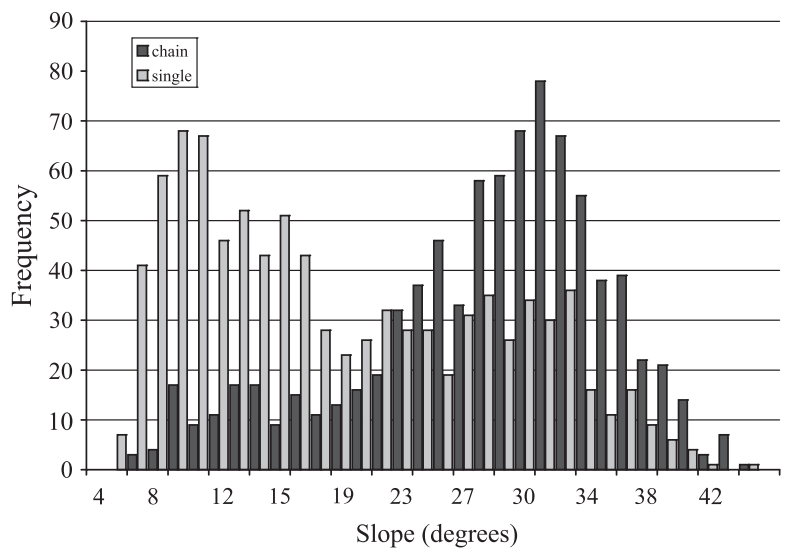

Fig. 13. Histogram of maximum slope gradient in degrees for single pockmarks (in gray) and chain pockmarks (in black).

pockmarks cannot develop in thin Holocene deposits, suggesting that Holocene sediment thickness controls pockmark size. Josenhans et al. (1978) and Fader (1991) on the Scotian Shelf and eastern Canadian continental shelf, respectively, also recognized a positive relation between pockmark size and sediment thickness.

Although depth to the unconformity limits maximum pockmark size in Belfast Bay, there are no obvious constraints on the low end of the size range. Yet, minimum-size statistics indicate that smaller pockmarks $(d<1.61 \mathrm{~m}, D<28.6 \mathrm{~m})$ do not occur in sediments thicker than $17.2 \mathrm{~m}$ (Table 4). This correlation most likely arises from the preference of percolating fluids for established conduits (Cathles et al., 2010). A previous Belfast Bay study suggested pockmark size and proximity to gas deposits may reflect fluid-migration pathways (Rogers et al., 2006). We found that pockmarks underlain by gas deposits occupied a broader range of pockmark depth than pockmarks in the thickest sediments (>17.2 m; Table 4). We interpret this broader size range to indicate that subsurface gas does not control pockmark size as strong as sediment thickness. While the lateral fluid- migration pathways and consequent origins of peripheral pockmarks proposed by Rogers et al. (2006) are possible, our results suggest, along with Fader (1991) that sediment thickness may fundamentally control both minimum and maximum pockmark sizes. Pockmark size and coincidence with subsurface gas may not reflect the mode of pockmark formation.

Pockmarks in Belfast Bay slope in excess of the proposed $20^{\circ}$ angle of repose, for fine-grained marine sediments (Booth et al., 1985). Although Oslofjord pockmarks also exceed this value, their mean slope $\left(13^{\circ}\right)$ is lower than the comparable features for Belfast Bay (Webb et al., 2009). Antecedent geology in the surveyed portion of Belfast Bay does not control individual pockmark slope. Previous studies suggested that slopes exceeding the angle of repose were indications of pockmark activity (Kelley et al., 1994; Webb et al., 2009). Although episodes of venting fluid may occur in Belfast Bay (Kelley et al., 1994), none was indicated in any of our data, or in a 1998 geochemical survey conducted by Ussler et al. (2003). Two studies suggest possible current rotational flow within pockmarks (Manley et al., 2004; Hammer et al., 2009). From current observations recorded in Oslofjord, Hammer et al. (2009) developed a numerical model that depicted upwelling currents within a pockmark. They postulated that such a current could minimize pockmark infilling; if this type of activity is occurring in Belfast Bay pockmarks it may, combined with geotechnical properties of the field, stabilize steeper slopes.

Chains of pockmarks occur throughout the Belfast Bay field, with the highest frequency in thicker sediments. Hovland et al. (2002), Rogers et al. (2006), Judd and Hovland (2007), and Pilcher and Argent (2007) have documented the association of pockmark chains with subsurface faulting, flexures or zones of weakness related to till outcrops. Our spatial assessment also finds that the longest chain ( $1 \mathrm{~km}, 51$ pockmarks) occurs sub-parallel to a till deposit in the north (Fig. 11), and that the most abundant clustering of pockmark chains occurs near the same deposit. However, prominent chains are absent at other till deposits in the field. We suggest that large pockmark chains correspond with maximum gradients in Holocene sediment thickness resulting from the irregular underlying topography. This is similar to Pinet et al.'s (2008) observation of linear pockmark fields along the bedrock-controlled scarp in the northwest side of the Laurentian Channel. Although the exact mechanisms for pockmark formation in Belfast Bay remain uncertain, field-wide morphology and chain distribution generally agree with observations in other fields where fluid escape is invoked in pockmark origins (Judd and Hovland, 2007).

\section{Conclusions}

We present a method for the extraction of seafloor pockmarks using the principles within geomorphometry, and established algorithms typically used for hydrologic analysis. This method successfully identified and extracted the seafloor depth of the top $\left(z_{1}\right)$, and bottom $\left(z_{2}\right)$ of each pockmark along with the perimeter $(p)$. In addition, our

Table 4

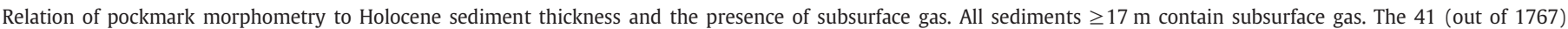
pockmarks (2\%) occurring south of our subsurface geophysical data are excluded from these statistics.

\begin{tabular}{|c|c|c|c|c|c|c|c|c|c|c|c|c|c|c|c|c|}
\hline \multirow[t]{2}{*}{ Isopach thickness (m) } & \multirow{2}{*}{$\begin{array}{l}\text { Number } \\
\text { pockmarks } \\
\text { in layer }\end{array}$} & \multicolumn{4}{|c|}{ Pockmark depth $d(\mathrm{~m})$} & \multicolumn{4}{|c|}{ Pockmark perimeter $p(\mathrm{~m})$} & \multicolumn{4}{|c|}{ Pockmark diameter $D(\mathrm{~m})$} & \multicolumn{3}{|c|}{ Pockmark chains } \\
\hline & & Min & Max & Mean & SD & Min & Max & Mean & SD & Min & Max & Mean & SD & $\#$ & $\%$ & $\begin{array}{l}\text { Chains } \\
n>5\end{array}$ \\
\hline $0-6.4$ & 220 & 0.64 & 4.31 & 2.06 & 0.62 & 60.0 & 810 & 191 & 111.0 & 19.1 & 258 & 60.8 & 35.3 & 37 & 17 & 7 \\
\hline $6.5-11.7$ & 471 & 0.55 & 8.82 & 3.73 & 1.50 & 60.0 & 530 & 191 & 69.2 & 19.1 & 169 & 60.8 & 22.0 & 129 & 27 & 37 \\
\hline $11.8-17.2$ & 365 & 0.71 & 13.50 & 7.25 & 2.20 & 50.0 & 740 & 251 & 78.2 & 15.9 & 236 & 80.9 & 24.9 & 177 & 48 & 77 \\
\hline $17.3-23.2$ & 261 & 1.85 & 16.20 & 12.70 & 3.00 & 100.00 & 760 & 355 & 104.0 & 31.2 & 242 & 113.0 & 33.1 & 168 & 64 & 86 \\
\hline $23.3-34.4$ & 409 & 1.61 & 25.40 & 13.50 & 4.06 & 90.0 & 560 & 372 & 117.0 & 28.6 & 302 & 118.0 & 37.2 & 298 & 73 & 19 \\
\hline Pockmarks underlain by gas & 417 & 1.22 & 25.40 & 12.10 & 5.03 & 90.0 & 950 & 341 & 128.0 & 28.6 & 302 & 109.0 & 40.7 & 288 & 69 & 168 \\
\hline
\end{tabular}


method calculated pockmark depth $(d)$ and diameter $(D)$ for the 1767 pockmarks identified within the study area. These empirically derived dimensions describe pockmark shape and distribution, and provide a new basis for comparison with other pockmark fields worldwide.

The morphology and non-random distribution of pockmarks in Belfast Bay are similar to those of other fields, including the occurrence of chains and a consistent depth-to-diameter relationship. However, Belfast Bay pockmarks have steeper slopes that exceed the critical angle for fine-grained sediments. As in other eastern North American pockmark fields, sediment thickness appears to influence pockmark size more than the presence of shallow gas.

\section{Acknowledgments}

We thank Richard Pike, Jason Chaytor, and Joe Kelley for helpful comments on earlier versions of this manuscript. A Maine Economic Improvement Fund Dissertation Fellowship provided graduate support for L. Brothers.

\section{References}

Barnhardt, W.A., Gehrels, W.R., Belknap, D.F., Kelley, J.T., 1995. Late Quaternary relative sea-level change in the western Gulf of Maine: evidence for a migrating glacial forebulge. Geology 23, 317-320.

Barnhardt, W.A., Belknap, D.F., Kelley, A.R., Kelley, J.T., Dickson, S.M., 1996. Geologic Map Series Nos. 96:7-13, Maine Geological Survey, Augusta, ME, 1:100, 000.

Barnhardt, W.A., Belknap, D.F., Kelley, J.T., 1997. Stratigraphic evolution of the inner continental shelf in response to late Quaternary relative sea-level change, northwestern Gulf of Maine. Geological Society of America Bulletin 109, 612-630.

Belknap, D.F., Shipp, R.C., 1991. Seismic stratigraphy of glacial marine units, Maine inner shelf. In: Anderson, J.B., Ashley, G.M. (Eds.), Glacial Marine Sedimentation; Paleoclimatic Significance. Geological Society of America. Special Paper 261. Geological Society of America, Boulder, pp. 137-157.

Belknap, D.F., Andersen, B.G., Anderson, R.S., Anderson, W.A., Borns Jr., H.W., Jacobson Jr., G., Kelley, J.T., Shipp, R.C., Smith, D.C., Stuckenrath Jr., R., Thompson, W.B., Tyler, D.A., 1987. Late Quaternary sea-level changes in Maine. In: Nummedal, D., Pilkey Jr., O.H., Howard, J.D. (Eds.), Sea-Level Fluctuation and Coastal Evolution: Society of Economic Paleontologists and Mineralogists Special Pub, Tulsa, 41, pp. 71-85.

Bloom, A.L., 1963. Late-Pleistocene fluctuations of sea level and postglacial and crustal rebound in coastal Maine. American Journal of Science 261, 862-879.

Booth, J.S., Sangrey, D., Fugate, J., 1985. A nomogram for interpreting slope stability of fine-grained deposits in ancient and modern marine environments. Journal Sedimentary Petrology 55, 29-36.

Cathles, L.M., Su, Z., Chen, D., 2010. The physics of gas chimney and pockmark formation, with implications for assessment of seafloor hazards and gas sequestration. Marine and Petroleum Geology 27, 82-91.

Dorion, C.C., Balco, G.A., Kaplan, M.R., Kreutz, K.J., Wright, J.D., Borns Jr., H.W., 2001. Stratigraphy, paleoceanography, chronology, and environment during deglaciation of eastern Maine. In: Weddle, T.K., Retelle, M.J. (Eds.), Deglacial History and Relative Sea-Level Changes Northern New England and Adjacent Canada: Geological Society of America Special Paper, 351, pp. 215-242. Boulder.

Fader, G.B.J., 1991. Gas-related sedimentary features from the eastern Canadian continental shelf. Continental Shelf Research 11, 1123-1154.

Gallant, J.C., Wilson, J.P., 2000. Primary topographic attributes. In: Wilson, J.P., Gallant, J.C. (Eds.), Terrain Analysis: Principles and Applications. John Wiley and Sons Press, New York, pp. 51-85.

Gontz, A.M., Belknap, D.F., Kelley, J.T., 2002. Seafloor features and characteristics of the Black Ledges area, Penobscot Bay, Maine, USA. Journal of Coastal Research 36, 333-339.

Hammer, Ø., Webb, K.E., Depreiter, D., 2009. Numerical simulation of upwelling currents in pockmarks, and data from the Inner Oslofjord, Norway. Geo-Marine Letters 29, 269-275.

Hengl, T., Reuter, H.I. (Eds.), 2009. Geomorphometry: Concepts, Software, Applications. Developments in Soil Science, 33. Elsevier, Amsterdam, p. 772.

Hovland, M., Judd, A.G., 1988. Seabed Pockmarks and Seepages: Impact on Geology, Biology, and the Marine Environment. Graham and Trotman Ltd., London. 293 pp.

Hovland, M., Gardner, J.V., Judd, A.G., 2002. The significance of pockmarks to understanding for processes and geohazards. Geofluids 2, 127-136.

Hughes Clarke, J.E., Mayer, L.A., Wells, D.E., 1996. Shallow-water imaging multibeam sonars: a new tool for investigating seafloor processes and the coastal zone and the continental shelf. Marine Geophysical Researches 18, 607-629.

Jenson, S.K., Domingue, J.O., 1988. Extracting topographic structure from digital elevation data for Geographic Information System analysis. Photogrammetric Engineering and Remote Sensing 54, 1593-1600.
Josenhans, H.W., King, L.H., Fader, G.B., 1978. Side-scan sonar mosaic of pockmarks on Scotian Shelf. Canadian Journal of Earth Science 15, 831-840.

Judd, A.G., Hovland, M., 2007. Seabed Fluid Flow: Impact on Geology, Biology, and the Marine Environment. Cambridge University Press, Cambridge. 475 pp.

Kelley, J.T., 1987. An inventory of coastal environments and classification of Maine's glaciated shoreline. In: FitzGerald, D.M., Rosen, P.S. (Eds.), Glaciated Coasts. Academic Press, San Diego, pp. 151-176.

Kelley, J.T., Belknap, D.F., 1991. Physiography, surficial sediments and Quaternary stratigraphy of the inner continental shelf and nearshore region of central Maine, United States of America. Continental Shelf Research 11, 1265-1283.

Kelley, J.T., Dickson, S.M., Belknap, D.F., Barnhardt, W.A., Henderson, M., 1994. Giant sea-bed pockmarks: evidence for gas escape from Belfast Bay, Maine. Geology 22 59-62.

Kelley, J.T., Barnhardt, W.A., Belknap, D.F., Dickson, S.M., Kelley, A.R., 1998. The Seafloor Revealed: the Geology of the Northwestern Gulf of Maine Inner Continental Shelf, Maine Geological Survey Open-File 96-6. 55 pp.

Kelley, J.T., Belknap, D.F., Claesson, S., 2010. Drowned coastal deposits with associated archaeological remains from a sea-level "slowstand": northwestern Gulf of Maine, USA. Geology 38, 695-698.

King, L.H., MacLean, B., 1970. Pockmarks on the Scotian Shelf. Geological Society of America Bulletin 81, 3141-3148.

Knebel, H.J., 1986. Holocene depositional history of a large glaciated estuary, Penobscot Bay. Marine Geology 73, 215-236.

Manley, P.L., Manley, T.O., Watzin, M.C., Gutierrez, J., 2004. Lakebed pockmarks in Burlington Bay, Lake Champlain: I. Hydrodynamics and implications of origin. In: Manley, T.O., Manley, P.L., Mihuc, T.B. (Eds.), Lake Champlain: Partnerships and Research in the New Millennium. Springer, Berlin Heidelberg New York pp. 299-330.

Osberg, P.H., Hussey, A.M. II, Boone, G.M., (Eds.), 1985. Bedrock Geologic Map of Maine: Maine Geological Survey, Augusta, ME, 1:500,000.

Ostericher Jr., C., 1965. Bottom and subbottom investigations of Penobscot Bay, Maine 1959. Naval Oceanographic Office Technical Report TR-173, Washington D.C. 177 pp.

Pike, R.J., 1995. Geomorphometry - process, practice and prospect. Zeitschrift für Geomorphologie, Supplementalband 101, 221-238.

Pike, R.J., 2000. Geomorphometry - diversity in quantitative surface analysis. Progress in Physical Geography 24, 1-20.

Pike, R.J., Evans, I.S., Hengl, T., 2009. Geomorphometry: a brief guide. In: Hengl, T., Reuter, H.I. (Eds.), Geomorphometry: Concepts, Software, Applications. Developments in Soil Science, 33. Elsevier, Amsterdam, pp. 1-28.

Pilcher, R., Argent, J., 2007. Megapockmark and linear pockmark trains on the West African Continental margin. Marine Geology 244, 15-22.

Pinet, N., Duchesne, M., Lavoie, D., Bolduc, A., Long, B., 2008. Surface and subsurface signatures of gas seepage in the St. Lawrence Estuary (Canada): significance to hydrocarbon exploration. Marine and Petroleum Geology 25, 271-288.

Reimer, P.J., Baillie, M.G.L., Bard, E., Bayliss, A., Beck, J.W., Blackwell, P.G., Bronk Ramsey, C., Buck, C.E., Burr, G.S., Edwards, R.L., Friedrich, M., Grootes, P.M., Guilderson, T.P., Hajdas, I., Heaton, T.J., Hogg, A.G., Hughen, K.A., Kaiser, K.F., Kromer, B., McCormac, F.G., Manning, S.W., Reimer, R.W., Richards, D.A., Southon, J.R., Talamo, S., Turney, C.S.M., van der Plicht, J., Weyhenmeyer, C.E., 2009. IntCal09 and Marine09 radiocarbon age calibration curves, 0-50, 000 years cal BP. Radiocarbon 51, $1111-1150$.

Rogers, J.N., 1999. Mapping of subaqueous, gas-related pockmarks in Belfast Bay, Maine using GIS and remote sensing techniques. MS Thesis, Department of Earth Sciences, University of Maine, Orono, ME, 139 pp.

Rogers, J., Kelley, J.T., Belknap, D.F., Gontz, A., Barnhardt, W.A., 2006. Shallow-water pockmark formation in temperate estuaries: a consideration of origins in the western gulf of Maine with special focus on Belfast Bay. Marine Geology 225, 45-62.

Scanlon, K.M., Knebel, H.J., 1989. Pockmarks in the floor of Penobscot Bay, Maine. GeoMarine Letters 10, 53-58.

Schubel, J.R., 1974. Gas bubbles and the acoustically impenetrable, or turbid, character of some estuarine sediments. In: Kaplan, I.R. (Ed.), Natural Gases in Marine Sediments. Plenum Press, New York, pp. 275-298.

Shipp, R.C., Staples, S.A., Ward, L.G., 1987. Controls and Zonation of Geomorphology Along a Glaciated Coast, Gouldsboro Bay, Maine. In: FitzGerald, D.M., Rosen, P.S. (Eds.), Glaciated Coasts. Academic Press, San Diego, CA, pp. 209-231.

Song, G.S., 2007. Side-scan sonographs of steep slopes in the Wushieh Reservoir International Journal of Remote Sensing 28, 1857-1871.

Ussler III, W., Paull, C.K., Boucher, J., Friederich, G.E., Thomas, D.J., 2003. Submarine pockmarks: a case study from Belfast Bay, Maine. Marine Geology 202, 175-192.

Webb, K.E., Hammer, Ø., Lepland, A., 2009. Pockmarks in the inner Oslofjord, Norway. Geo-Marine Letters 29, 111-124.

Wildish, D.J., Akagi, H.M., McKeown, D.L., Pohle, G.W., 2008. Pockmarks influence benthic communities in Passamaquoddy Bay, Bay of Fundy, Canada. Marine Ecology Progress Series 357, 51-66.

Yun, J.W., Orange, D.L., Field, M.E., 1999. Subsurface gas offshore of northern California and its link to submarine geomorphology. Marine Geology 154, 357-368. 